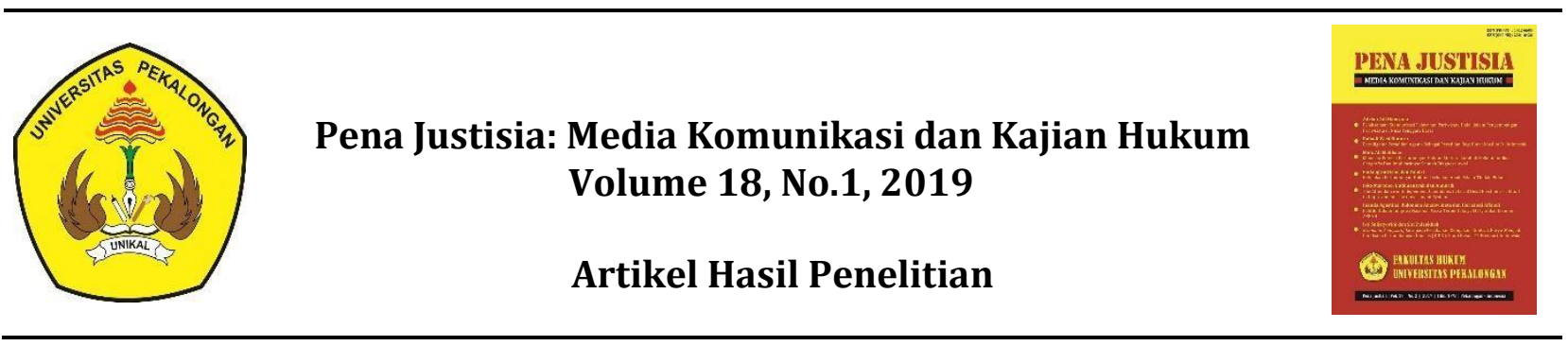

\title{
PENERAPAN BANTUAN HUKUM DALAM PROSES PENYIDIKAN DENGAN PRINSIP ACCUSATOIR
}

\author{
Muhammad Rusli Arafat**
}

**Program Pascasarjana Fakultas Hukum Universitas Padjadjaran, Email: muhammadrusliarafat@gmail.com

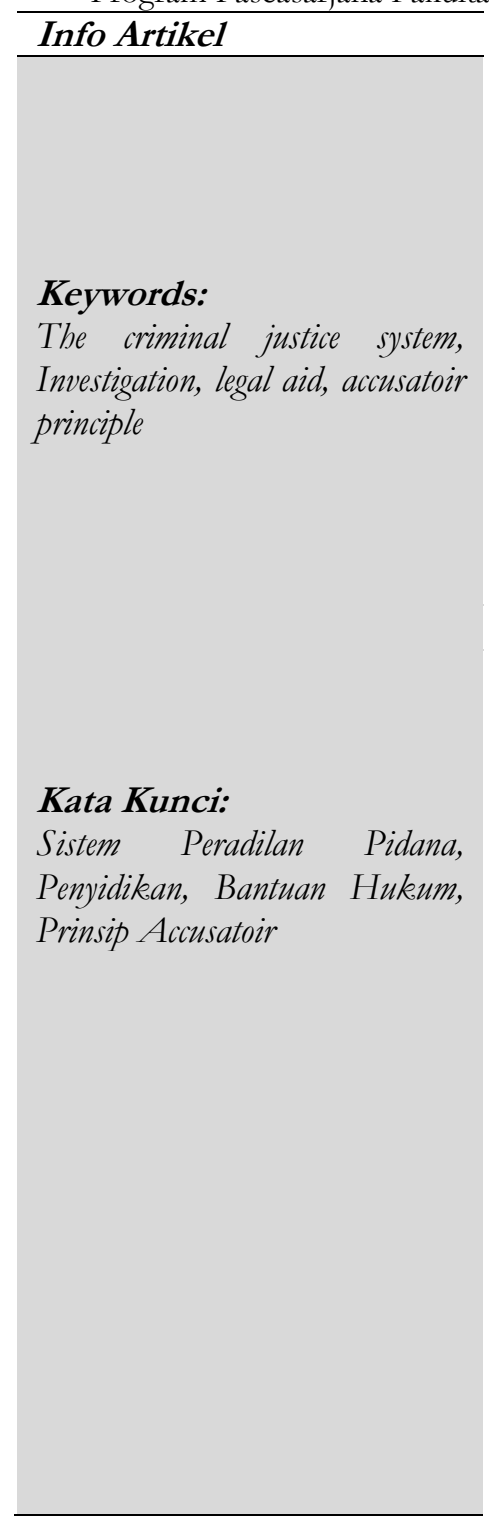

\begin{abstract}
Investigation of criminal case through the criminal justice system must to base on the appropriate processes and procedure that can be accounted. One of the important procedures to investigation is the right to get legal protection. Legal protection is one of the fundamental rights that every human being possesses, one form of legal protection is right to obtain legal aid in every steps of investigation process. The legal aid has an important meaning for someone who dealing with legal issues. This research is discussed about application of legal aid in the process of police investigation. This research also specializes in the approach using the rule of national law (legislation) to be able to know the application of legal aid with the principle of accusatoir. The result of this research is Legal aid can reduce the number of violence in the process of investigation of suspects by the police (investigation) in order to protect the human rights of the suspect, the role of legal aid is needed, the number of investigation of suspects not accompanied by advocate it cause torture of the suspect, because the investigator considers the suspect to be an object of inspection instead of placing the suspect as the subject of the investigation.
\end{abstract}

Abstrak
Pemeriksaan perkara pidana melalui sistem peradilan pidana tentu saja harus
berdasarkan proses-proses atau procedure yang tepat dan mampu
dipertanggungjawabkan. Salah satu prosedur penting dalam pemeriksaan
yakni adanya hak untuk mendapat perlindungan hukum. Perlindungan
hukum adalah salah satu hak mendasar yang dimiliki oleh setiap manusia,
salah satu perwujudan dari perlindungan hukum adalah hak untuk
mendapatkan bantuan hukum dalam setiap proses pemeriksaan. Bantuan
hukum memiliki arti yang sangat penting bagi seseorang yang sedang
berhadapan dengan masalah hukum. Penelitian membahas tentang
penerapan bantuan hukum dalam proses penyidikan yang dilakukan oleh
kepolisian. Penelitian ini juga mengkhususkan pada pendekatan dengan
menggunakan aturan hukum nasional (perundang-undangan) untuk dapat
mengetahui penerapan bantuan hukum dengan prinsip accusatoir. Setelah
dilakukan penelitian hasil yang diperoleh adalah Bantuan hukum dapat
menekanangka kekerasan pada proses pemeriksaan tersangka oleh kepolisian
(penyidikan) dalam rangka melindungi Hak Asasi Manusia terhadap
tersangka, maka peran bantuan hukum sangat dibutuhkan, banyaknya
pemeriksaan tersangka yang tidak didampingi penasihat hukum
menyebabkan terjadinya penyiksaan terhadap diri tersangka, hal tersebut
kerap dilakukan karena penyidik menganggap tersangka adalah obyek
pemeriksaan bukan menempatkan tersangka sebagai subyek pemeriksaan.




\section{PENDAHULUAN}

Sistem peradilan pidana (criminal justice system) secara sederhana adalah proses yang dilakukan oleh negara terhadap orang-orang yang melanggar hukum pidana. Proses ini melibatkan beberapa sub sistem dalam sistem peradilan pidana, yaitu kepolisian, kejaksaan, dan pengadilan. Sistem peradilan pidana itu tidak hanya mencakup institusi, tetapi berkaitan erat dengan beberapa institusiinstitusi negara, sehingga pekerjaan aparatur penegak hukum yang satu, akan berdampak pada beban kerja kepada penegak hukum dalam sistem peradilan pidana adalah terpadu dan tidak dapat dipisahkan. ${ }^{1}$ Menurut muladi dalam bukunya menjelaskan bahwa subsitem dalam sistem peradilan pidana tidak hanya terbatas pada lembaga pengadilan saja. Sistem peradilan pidana di dalamnya terkandung gerak sistemik dari subsistem-subsistem pendukungnya yaitu, kepolisian, kejaksaan, pengadilan dan lembaga koreksi (lembaga pemasyarakatan) yang secara keseluruhan dan merupakan suatu kesatuan (totalitas) berusaha mentransformasikan masukan (input) menjadi keluaran (output) yang menjadi tujuan sistem peradilan pidana yang berupa resosialisasi pelaku tindak pidana (jangka pendek), pencegahan kejahatan (jangka menengah), dan kesejahteraan sosial (jangka panjang). ${ }^{2}$

Tujuan hukum acara pidana dalam sistem peradilan pidana adalah untuk mencari dan menetapkan kebenaran materil, dengan tujuan mencari kebenaran materil oleh pengadilan tentu saja harus berada dalam proses-proses atau procedure yang tepat dan mampu dipertanggungjawabkan. Dalam sistem peradilan pidana dikenal beberapa pendekatan dalam menemukan kebenaran materiil tersebut. Salah satu pendekatan yang digunakan adalah due process model, model ini menekankan seluruh temuan-temuan fakta dari suatu kasus, yang harus diperoleh melalui prosedur formal yang sudah ditetapkan oleh undang-undang. Setiap prosedur adalah penting dan tidak boleh diabaikan, melalui suatu tahapan pemeriksaan yang ketat mulai dari penyidikan, penangkapan, penahanan dan peradilan serta adanya suatu reaksi untuk setiap tahap pemeriksaan, maka dapat diharapkan seorang tersangka yang nyata-nyata tidak bersalah akan dapat memperoleh kebebasan dari tuduhan melakukan kejahatan. ${ }^{3}$

Selain daripada sub sistem dalam peradilan pidana, hal yang tidak kalah penting dalam rangka penegakan hukum pidana melalui hukum acara pidana adalah bantuan hukum terhadap tersangka. Bantuan hukum yang diberikan tidak lain adalah sebagai proses pembelaan terhadap diri terdakwa serta bertujuan untuk melindungi hak-hak hukum tersangka terlebih tesangka tersebut buta hukum. Bantuan hukum yang diberikan kepada tersangka idealnya diberikan pada awal perkara tersebut mulai di proses di kepolisian sampai dengan proses hingga tersangka selesi menjalani masa hukuman. Pentingnya bantuan hukum lainnya adalah perlindungan tersangka dari kesewenanagwenangan aparat penegak hukum yang seringkali memposisikan terdakwa sebagai obyek (inkuisitoir). Sehingga seringkali dalam melakukan pemeriksaan aparat penegak hukum melakukan tindakan-tindakan yang justru merugikan tersangka. Dalam negara hukum semua orang harus diperlakukan sama di hadapan hukum (equality before the law). ${ }^{4}$

Hak untuk mendapat perlindungan hukum adalah salah satu hak mendasar yang dimiliki oleh setiap manusia, salah satu perwujudan dari perlindungan hukum adalah hak untuk mendapatkan bantuan hukum. Bantuan hukum memiliki arti yang sangat penting bagi seseorang yang sedang berhadapan dengan masalah hukum, apalagi bila orang tersebut "buta hukum", oleh sebab itu Pemerintah telah mengatur masalah bantuan hukum dalam beberapa undang-undang, yaitu Undang-Undang Nomor 8 Tahun 1981 tentang Hukum Acara Pidana (KUHAP), Undang-Undang Nomor 8 Tahun 2003 tentang Advokat dan Undang-Undang Nomor 48 Tahun 2009 tentang Kekuasaan Kehakiman. Dan yang terbaru adalah Undang-Undang Nomor 16 Tahun 2011 tentang

\footnotetext{
${ }^{1}$ Syaiful Bakhri, 2014, Sistem Peradilan Pidana Di Indonesia, Yogyakarta: Pustaka Pelajar hlm. 7

2 Muladi, 1995, Kapita Selekta Sistem Peradilan Pidana, Semarang: BP Universitas Diponegoro.

${ }^{3}$ Romli Atmasasmita, 1995, Kapita Selekta Hukum Pidana dan Kriminologi, Bandung: Mandar Maju.

${ }^{4}$ Syaiful Bakhari, 2014, Sistem Peradilan Pidana Indonesia Prespektif Pembaharuan Teori dan Praktik Peradilan, Yogyakarta: Pustaka Pelajar. Hlm. 72
} 
Bantuan Hukum Lahirnya undang-undang tentang bantuan hukum semakin mempertegas kedudukan penting suatu bantuan hukum dalam proses penegakan hukum di Indonesia.

Undang-Undang No. 16 Tahun 2011 tentang Bantuan Hukum (UUBH) memberi peluang terhadap perlindungan hak warga Negara yang sedang menjalani proses hukum. Ada dua latar belakang yang menjadi dasar pembentukan UUBH, yaitu pertama, jaminan negara terhadap hak konstitusional setiap orang untuk mendapatkan pengakuan, jaminan, perlindungan dan kepastian hukum yang adil serta perlakuan yang sama di depan hukum sebagai sarana perlindungan HAM. Kedua, Negara bertanggung jawab terhadap pemberian bantuan hukum bagi sebagai perwujudan akses terhadap keadilan. Bantuan hukum yang dimaksud dalam UUBH yaitu lembaga bantuan hukum atau organisasi yang memberikan layanan bantuan hukum secara cuma-cuma kepada penerima bantuan hukum. Secara garis besar, tujuan bantuan hukum yang tercantum dalam Pasal 3 UUBH adalah mewujudkan akses kepada keadilan bagi masyarakat miskin dan juga mewujudkan peradilan yang efektif, efisien, dan dan dapat dipertanggungjawabkan (akuntabel). Jadi bantuan hukum tidak semata untuk memberikan jasa hukum bagi masyarakat akan tetapi sekaligus diharapkan mampu mendorong perbaikan sistem peradilan. ${ }^{5}$ Berangkat dari penjabaran dan penjelasan sebelumnya, maka tulisan ini akan membahas mengenai peran bantuan hukum dalam teknis penyidikan dengan prinsip accusatoir dalam rangka reformasi hukum acara pidana, yang di analisa menggunakan pendekatan normatif.

\section{PEMBAHASAN}

\section{Bantuan Hukum dalam Proses Penyidikan dengan Prinsip Accusatoir}

Sistem peradilan pidana (SPP) untuk pertama kali diperkenalkan oleh pakar hukum pidana dan ahli dalam criminal justice system di Amerika Serikat sejalan dengan ketidakpuasan terhadap mekanisme kerja aparatur penegak hukum dan institusi penegak hukum. Ketidakpuasan ini terbukti dari meningkatnya kriminalitas di Amerika Serikat pada tahun 1960-an. ${ }^{6}$ Pada masa itu pendekatan yang dipergunakan dalam penegakan hukum adalah "hukum dan ketertiban" (law and order approach) dan penegakan hukum dalam konteks pendekatan tersebut dikenal dengan istilah "law enforcement". Barda Nawawi Arief mengartikan SPP sebagai suatu proses penegakan hukum pidana. Oleh karena itu berhubungan erat dengan perundang-undangan pidana itu sendiri, baik hukum pidana substantif maupun hukum acara pidana. Pada dasarnya, lanjut Barda Nawawi Arief, Perundangundangan pidana merupakan penegakan hukum pidana in abstracto yang akan diwujudkan ke dalam penegakan hukum in concrecto. ${ }^{7}$ Norvel Morris sebagaimana dikutip Mardjono Reksodiputro, mengatakan bahwa:

"Sistem Peradilan Pidana adalah suatu operasionalisasi atau suatu sistem yang bertujuan untuk menanggulangi kejahatan, salah satu usaha masyarakat untuk mengendalikan terjadinya kejahatan negara berada dalam batas-batas toleransi yang dapat diterima. Sistem ini dianggap berhasil apabila sebagian besar dari laporan masyarakat yang menjadi korban kejahatan dapat diselesaikan dengan diajukannya pelaku kejahatan ke sidang pengadilan dandiputus bersalah serta mendapat pidana".

Herbert Packer, mengungkapkan bahwa dalam melaksanakan mekanisme proses peradilan pidana digunakan pendekatan normatif yang berorientasi pada nilai-nilai praktis. Terdapat dua model dalam pendekatan dikotomi. yaitu crime control model (CCM) dan due process model (DPM). Dua

\footnotetext{
${ }^{5}$ Chrisbiantoro, M Nur Sholikin, Satrio Wirataru, 2014, Bantuan Hukum Masib Sulit Diakses : Hasil Penelitian Di Lima Provinsi Terkait Pelaksanaan Undang-Undang No. 16 Tabun 2011 Tentang Bantuan Hukum, Jakarta: KontraS. Hlm. 2

${ }^{6}$ Romli Atmasasmita, 1996, Sistim Peradilan Pidana Perspektif Eksistensialisme dan Abolisionisme, Bandung: Bina Cipta, Hlm 6-7.

${ }^{7}$ Barda Namawi Arif, 1992, Teori-Teori dan Kebijakan Pidana, Bandung: Alumni bandung, Hlm 197.

8 Mardjono Reksodiptro, 1994, Kriminologi dan Sistem Peradilan Pidana, Kumpulan karangan buku kedua, Jakarta: Lembaga Kriminologi Universitas Indonesia, Hlm 140
} 
model ini, merupakan antinomi normatif di pusat hukum pidana. Keduanya berupaya mengabtrasikan dua sistem nilai yang berbeda dalam pelaksanaan proses peradilan pidana. ${ }^{9}$

Pertama, Crime Control Model, pemberantasan kejahatan merupakan fungsi terpenting dan harus diwujudkan dari suatu proses peradilan pidana, sehingga perhatian utama harus ditujukan pada efisiensi proses peradilan pidana. Titik tekan pada model ini adalah efektifitas, yaitu kecepatan dan kepastian. Pembuktian kesalahan tersangka sudah diperoleh di dalam proses pemeriksaan oleh petugas kepolisian. Presumption of guilty digunakan untuk mempercepat memproses tersangka atau terdakwa ke sidang pengadilan. Nilai-nilai yang melandasi crime control model adalah tindakan represif terhadap suatu tindakan kriminal merupakan fungsi terpenting dari suatu proses peradilan. Perhatian utama harus ditujukan kepada efisiensi dari suatu penegakan hukum untuk menyeleksi tersangka, menetapkan kesalahannya dan menjamin atau melindungi hak tersangka dalam proses peradilan. Proses criminal penegakan hukum harus dilaksahakan berlandaskan prinsip cepat dan tuntas, dan model yang dapat mendukung proses penegakan hukum tersebut adalah model administratif dan merupakan model manajerial. Asas praduga tak bersalah akan menyebabkan sistem ini dilaksanakan secara efisien. Proses penegakan hukum harus menitikberatkan kepada kualitas temuan-temuan fakta administratif, oleh karena temuan tersebut akan membawa ke arah pembebasan seorang tersangka dari penuntutan, atau kesediaan tersangka menyatakan dirinya bersalah.

Kedua, Due Process Model (DPM), model ini menekankan seluruh temuan-temuan fakta dari suatu kasus, yang harus diperoleh melalui prosedur formal yang sudah ditetapkan oleh undang-undang. Setiap prosedur adalah penting dan tidak boleh diabaikan, melalui suatu tahapan pemeriksaan yang ketat mulai dari penyidikan, penangkapan, penahanan dan peradilan serta adanya suatu reaksi untuk setiap tahap pemeriksaan, maka dapat diharapkan seorang tersangka yang nyata-nyata tidak bersalah akan dapat memperoleh kebebasan dari tuduhan melakukan kejahatan. Presumption of innocence merupakan tulang punggung model ini. Adapun nilai-nilai yang melandasi due process model adalah mengutamakan, formal-adjudicative dan adversary fact findings, hal ini berarti dalam setiap kasus tersangka harus diajukan ke rnuka pengadilan yang tidak memihak dan diperiksa sesudah tersangka rnemperoleh hak yang penuh untuk mengajukan pembelaannya. Menekankan pada pencegahan dan menghapuskan sejauh mungkin kesalahan mekanisme administrasi dan peradilan. Konsep due process model, sangat menjunjung tinggi supremasi hukum, dalam perkara pidana tidak seorang pun berada dan menempatkan diri di atas hukum. Setiap penegakan hukum harus seusai dengan persyaratan konstitusional, harus menaati hukum, serta harus menghormati the right of self incrimination. Tidak seorangpun dapat dipaksa menjadi saksi yang memberatkan dirinya dalam suatu tindak pidana. Dilarang mencabut, menghilangkan hak hidup, kemerdekaan, atau harta benda tanpa sesuai dengan ketentuan hukum acara. ${ }^{10}$

Pada hakikatnya, dengan memperlakukan para tersangka atau terdakwa (khususnya mereka yang berada dalam tahanan) sesuai dengan hak-haknya, berarti secara tidak langsung para aparat penegak hukum telah melakukan proses pembinaan. Paling tidak, seorang tersangka/ terdakwa dapat mengetahui hak-haknya ketika pertama kali bersentuhan dengan proses hukum yang melibatkan dirinya. Dengan demikian proses pembinaan terhadap seseorang yang terlibat dalam suatu kasus tidak selalu harus berstatus narapidana. Proses pembinaan terhadap para tahanan di sini tentunya tidak perlu sama dengan seorang narapidana. Namun prinsip dasarnya harus sama. Peranan institusi, bantuan hukum dianggap penting dalam rangka penegakan HAM, khususnya dalam sistem peradilan pidana, di sinilah pentingnya mereka terkena kasus didampingi oleh penasehat hukumnya, karena tidak semua subjek hukum yang berhubungan dengan suatu perkara pidana memahami hak-

\footnotetext{
${ }^{9}$ Sudarto, 2006, Kapita Selekta Hukum Pidana, Bandung: PT Alumni, Hlm 73

10 Aswanto, 1999, Jaminan Perlindungan Hak Asasi Manusia dalam KUHAP dan Peranan Bantuan Hukum terhadap Penegakan Hak Asasi Manusia di Indonesia, Disertasi, Surabaya : Unair, Hlm 248.
} 
haknya, termasuk tindakan apa yang harus dilakukan serta bagaimana prosedur mempertahankan dan mendapatkan hak-haknya tersebut. ${ }^{11}$

Pembelaan terhadap tersangka/ terdakwa mutlak diperlukan dalam suasana sistem hukum pidana yang belum mencapai titik keterpaduan (Integrated Criminal Justice System). Seringkali tersangka karena tidak tahu hak-haknya sebagai tersangka/terdakwa disiksa. Model pemeriksaan yang masih mengutamakan pengakuan sebagai target utama menyebabkan kepolisian masih memelihara model inkuisitur yang menjadikan tersangka sebagai objek saja, dengan kekerasan sebagai modus utama untuk mendapatkan pengakuan. Kekerasan dimungkinkan karena pada saat diperiksa, tersangka tidak didampingi penasehat hukum. Kekerasan ini menyebabkan tersangka luka atau memar pada tubuhnya dan secara pisikis jiwanya tertekan. Seringkali terjadi kekerasan dilakukan usai tersangka ditangkap, yang seharusnya pada saat itu hak pelaku kejahatan sebagai tersangka sudah harus dipenuhi. Modus yang terjadi adalah dipukuli, dibentak dan ditodong pistol serta diancam akan ditahan jika tidak mengakui perbuatannya. ${ }^{12}$ Polisi belum bekerja menerapkan Due Process Model yang memperhatikan hak-hak tersangka sejak ditangkap. Ia dianggap tidak bersalah sampai nanti dibuktikan oleh putusan pengadilan yang telah mempunyai ketetapan hukum oleh pengadilan yang bebas dan imparsial (independent and impartial judiciary), jujur, dan terbuka. Polisi masih cenderung menggunakan Crime Control Model.

Belum tercapainya peradilan yang independent dan imparsial telah menyebabkan sistem peradilan pidana di Indonesia tidak berfungsi maksimal. Putusan-putusan pengadilan banyak yang kontroversial dan kurang pertimbangan hukumnya. ${ }^{13}$ Pengadilan cenderung lebih memihak kepada pemerintah daripada masyarakat. Contohnya saja yang terjadi pada kasus Marsinah, Marsinah yang merupakan aktivis buruh migrant yang disiksa aparat keamanan dan meninggal, tetapi dalam pemeriksaan pengadilan sampai dengan putusannya tidak terungkap siapa pelaku pembunuhannya. Serta kasus kekerasan lainnya yang dialami oleh tersangka pada saat penyidikan oleh kepolisian. ${ }^{14}$ Telah diuraikan sebelumnya, di dalam suatu Negara hukum, Negara dan individu harus berdiri sejajar (on equal footing), Negara akan menjadi kuat kalau masyarakatnya juga kuat. Kekuasaan Negara dibatasi oleh hak asasi manusia. Semua perbuatan Negara dibatasi dan diatur hukum. Negara dibatasi hak asasi manusia agar tidak melanggar hak-hak individu serta sewenang-wenang atau menyalahgunakan kekuasaanya. ${ }^{15}$

Bentuk perlindungan, pemajuan, penegakan dan pemenuhan hak asasi manusia dalam hal ini adalah adanya pemberian bantuan hukum terhadap individu maupun kelompok yang mendapatkan permasalahan hukum. Seperti yang telah dijelaskan diatas bahwa secara konstitusi pemberian bantuan hukum sangat jelas dijamin maka pemerintah dengan kewenangan yang dimiliki telah mengatur lebih khusus mengenai pemberian bantuan hukum yang tidak lain adalah salah satu bentuk tanggung jawab Negara terhadap warganegaranya, oleh karena itu pemerintah dengan mengundangkan Undang-Undang Nomor 14 Tahun 1970 tentang Ketentuan-ketentuan Pokok Kekuasaan Kehakiman sebagaimana telah diubah dengan Undang-Undang Nomor 35 Tahun 1999 tentang Perubahan Atas Undang-Undang Nomor 14 Tahun 1970 tentang Ketentuan-ketentuan Pokok Kekuasaan Kehakiman kemudian diubah dengan Undang-Undnag No. 48 tahun 2009 tentang Kekuasaan Kehakiman yaitu pada Pasal 56 bahwa"Setiap orang yang tersangkut perkara berhak memperoleh bantuan hukum”. Peran pemerintah dalam melindungi hak asasi manusia terkhusus bantuan hukum selanjutnya telah ternyata diatur dalam Undang-Undang Nomor 8 Tahun

${ }^{11}$ Ibid., Hlm 248

${ }^{12}$ Agus Raharjo, Angkasa, Perlindungan Hukum Terbadap Tersangka Dalam Penyidikan Dari Kekerasan Penyidik Di Kepolisian Resort Banyumas. Mimbar Hukum, Volume 23 Nomor 1, Februari 2011, Hlm 81

${ }^{13}$ Frans Hendra Winata I, 2011, Bantuan Hukum Di Indonesia "Hak Untuk Didampingi Penasihat Hukum Bagi Semua Warga

Negara, Jakarta: PT Elex Media Komputindo, Hlm. 110

14 Ibid., Hlm. 111

15 Ibid., Hlm. 125 
1981 tentang Kitab Undang-undang Hukum Acara Pidana (KUHAP) yaitu pada Pasal 54 yang menegaskan bahwa guna kepentingan pembelaan, tersangka atau terdakwa berhak mendapat bantuan hukum dari seseorang atau lebih penasihat hukum selama dalam waktu dan pada setiap tingkat pemeriksaan. ${ }^{16}$

Bantuan hukum sebagai bantuan yang diberikan oleh para ahli, kepada mereka yang memerlukan perwujudan atau realisasi dari hak-haknya, serta perlindungan hukum. Pendapat lain disampaikan oleh Erni Widhayanti, bantuan hukum pada hakikatnya adalah upaya pemberian bantuan hukum dan pelayanan hukum kepada mayarakat, agar memperoleh dan menikmati haknya yang diberikan oleh hukum dalam proses peradilan pidana. Pada Seminar pembinaan profesi hukum didapat pengertian bantuan hukum adalah bantuan hukum terdiri dari bantuan hukum di dalam maupun di luar pengadilan. Pemberian bantuan hukum di dalam pengadilan menimbulkan masalah verplichte procurstelling yang berarti hak dan kewajiban mendapatkan bantuan hukum tersebut dilayani sebagai berikut $:^{17}$

1. Mewajibkan pengadilan untuk menunjuka secara langsung atau melalui organisasi profesi hukum advokat untuk mendampingi atau setiap orang yang berurusan di muka pengadilan.

2. Mewajibkan seseorang dari kalangan profesi untuk memberi bantuan hukum tersebut diatas.

Menurut Frans Hendra Winarta, pada dasarnya bantuan hukum adalah hak dari orang miskin yang dapat diperoleh tanpa bayar (pro bono publico) sebagai penjabaran persamaan hak di hadapan hukum. Adnan Buyung Nasution menyebutkan bahwa, bantuan hukum bagi orang atau kelompok orang miskin dapat diartikan sebagai pemberian jasa-jasa hukum (legal service) kepada orang yang tidak mampu secara ekonomis untuk menggunakan jasa-jasa advokat atau professional lanyers. ${ }^{18}$ Dari berbagai definisi bantuan hukum di atas dapat ditarik kesimpulan bahwa bantuan hukum merupakan jasa hukum yang khusus diberikan kepada fakir miskin yang memerlukan pembelaan secara cuma-cuma baik di luar maupun di dalam pengadilan secara pidana, perdata, dan tata usaha negara dari seseorang yang mengerti seluk-beluk pembelaan hukum, asas-asas dan kaidah, serta hak asasi manusia. ${ }^{19}$

Berdasarkan UUBH sesuai Pasal 1 angka (3) Pemberi Bantuan Hukum adalah lembaga bantuan hukum atau organisasi kemasyarakatan yang memberi layanan Bantuan Hukum berdasarkan Undang-Undang ini. Pemberian bantuan hukum menurut UUBH dilaksanakan oleh pemberi bantuan hukum yang sudah berbadan hukum, terakreditasi, memiliki kantor atau sekertariat tetap, memiliki pengurus dan program bantuan hukum. Kewajiban membela dan memberikan bantuan hukum bagi orang atau kelompok miskin oleh profesi advokat sejalan dengan prinsip justice for all dan persamaan di hadapan hukum dan hak untuk didampingi oleh advokat tanpa kecuali. Sangat pentingnya prinsip equality before the law dalam mewujudkan prinsip justice for all tersebut di atas, maka bantuan hukum merupakan hak mutlak atau hak asasi yang melekat pada setiap individu manusia, sehingga advokatlah yang sangat berperan, baik dari kompetensi maupun kewenangan dalam menjalankan fungsi bantuan hukum tersebut. Oleh karena perannya tersebut, maka negara mewajibkan advokat untuk memberikan bantuan hukum bagi orang atau kelompok miskin atau tidak mampu secara ekonomi. ${ }^{20}$

\footnotetext{
${ }^{16}$ Ibid., Hlm. 40

${ }^{17}$ Yolanda Putri Dewanti, Implementasi Bantuan Hukum Oleh Komisi Nasional Perlindungan Anak Kepada Anak Sebagai Korban Tindak Pidana, Skripsi, Fakultas Hukum, Universitas Jenderal Soedirman, Banyumas, 2013. Hlm. 16

18 Diah Ratna Sari Hariyanto, Bantuan Hukum Bagi Orang Atau Kelompok Orang Miskin Dalam Perkara Pidana Demi Terselenggaranya Proses Hukum Yang Adil Di Denpasar, Tesis, Fakultas Hukum, Universitas Udayana, Bali, 2014. Hlm. 45

${ }^{19}$ Frans Hendra Winarta II, 2009, Pro Bono Publico Hak Konstitusional Fakir Miskin Untuk Memperoleh Bantuan Hukum, Jakarta: PT Gramedia Pustaka Utama. Hlm. 23

${ }^{20}$ Ade Irawan Taufik, Sinergisitas Peran Dan Tanggung Jawab Advokat Dan Negara Dalam Pemberian Bantuan Hukum CumaCuma, Jurnal Rechtvinding, Volume 2 Nomor 1, April 2013. Jakarta: Pusat Penelitian dan Pengembangan Sistem Hukum Nasional Badan Pembinaan Hukum Nasional (BPHN) Kementerian Hukum dan HAM RI. Hlm. 49
} 
Setiap orang yang ditetapkan menjadi tersangka memiliki hak untuk mendapatkan bantuan hukum dalam setiap tahap pemeriksaan, sebagaimana di atur dalam Pasal 54 UU No. 8 Tahun 1981 tentang KUHAP, Pasal tersebut menentukan bahwa:

"Guna kepentingan pembelaan, tersangka/terdakwa berhak mendapat bantuan hukum baik

dari seorang atau lebih penasihat hukum selama dalam waktu dan pada setiap tingkat

pemeriksaan, menurut tatacara yang di atur dalam undang-undang ini”.

Pasal tersebut menjelaskan bahwa tersangka sejak dalam tahap pemeriksaan penyelidikan sudah boleh menikmati atau memperoleh haknya, salah satunya adalah hak untuk mendapat bantuan hukum dari penasihat hukum. Dalam UU No. 18 Tahun 2003 Pasal 22 Ayat 1 bahwa, advokat wajib memberikan bantuan hukum secara cuma-cuma kepada pencari keadilan yang tidak mampu. Ini memberikan suatu pemahaman, di mana hak tersangka merupakan jaminan dari hak asasi manusia (HAM), dengan adanya bantuan hukum dari penasihat hukum membantu memberikan perlindungan terhadap tersangka, dalam hal ini apa yang menjadi hak tersangka itu tidak dapat dicabut atau diganggu gugat. ${ }^{21}$

Bantuan hukum merupakan salah satu aspek yang menentukan apakah proses dalam sistem peradilan tersebut telah memberikan keadilan kepada masyarakat khususnya para tersangka/terdakwa. Pemberian bantuan hukum ini diberikan kepada setiap orang tanpa adaya diskriminasi, yaitu mendapatkan pendampingan dari advokat atau Lembaga Bantuan Hukum lainnya guna memperoleh bantuan atau jasa hukum selama proses pemeriksaan, baik pemeriksaan pada tingkat penyidikan maupun pada proses persidangan. ${ }^{22}$ Ketentuan Pasal 114 KUHAP merumuskan agar tersangka/terdakwa mendapatkan akses menuju keadilan maka diatur bahwa penyidik berkewajiban sebelum pemeriksaan dimulai, memberitahukan bahwa tersangka berhak mendapatkan bantuan hukum dari penasihat hukum/advokat, dan memberitahukan bahwa perkara yang dihadapinya mengharuskan dirinya dalam pemeriksaan didampingi penasihat hukum/advokat. Namun yang terjadi selama ini bukanlah demikian, seseorang yang dijadikan tersangka tidak langsung diberitahukan akan hak-hak hukumnya. Pemberitahuan dilakukan pada saat pemeriksaan dimulai, sehingga hal itu mengakibatkan tersangka tidak punya waktu dan kesempatan untuk mencari, menghubungi, dan berkonsultasi dengan penasihat hukum/advokat tentang perkara yang sedang dihadapinya. Pemberitahuan tersebut juga terkesan hanya formalitas.

Bantuan hukum terhadap tersangka atau terdakwa dalam perkara tindak pidana adalah bantuan hukum yang diberikan oleh advokat/pengacara mulai dari tingkat penyidikan sampai dengan pemeriksaan di sidang pengadilan. Bantuan hukum tersebut dapat berupa konsultasi hukum, mendampingi, membela dalam rangka kepentingan tersangka atau terdakwa selama proses pemeriksaan baik di penyidikan maupun di persidangan. ${ }^{23}$ Berkaitan dengan hak tersangka untuk mendapat bantuan hukum dalam proses penyidikan, diatur dalam Pasal 38 Undang-Undang Kekuasaan Kehakiman, yang menyebutkan bahwa dalam perkara pidana seorang tersangka sejak saat dilakukan penangkapan dan/atau penahanan berhak menghubungi dan meminta bantuan advokat. Pasal 114 KUHAP menyebutkan bahwa penyidik sebelum memulai pemeriksaan, wajib memberitahu atau memperingatkan tersangka akan haknya untuk mencari dan mendapatkan bantuan hukum dari seorang atau beberapa orang penasehat hukum. Penjelasan dari keterangan pasal tersebut dapat diketahui bahwa bantuan hukum merupakan hak dari tersangka, yang mana apabila tersangka tersebut menggunakan haknya, ia dapat mencari sendiri seorang penasehat hukum

${ }^{21}$ Heidy Visilia Sahanggamu, Hak Tersangka Untuk Mendapatkan Bantuan Hukum Dalam Proses Penyidikan Perkara Pidana, Lex Crimen, Vol. II No. 2 Apr-Jun 2013, Hlm. 162

22 Abdul Latif, Jaminan UUD 1945 dalam Proses Hukum yang Adil, Jurnal Konstitusi, Mahkamah Konstitusi Vol. 7 No. 1. Februari, 2010, Hlm. 52

23 Anggi Rahmatika, Pemberian Bantuan Hukum Terhadap Pelaku Tindak Pidana Terorisme Menurut Undangundang Nomor 16 Tahun 2011 Tentang Bantuan Hukum, Skripsi, Fakultas Hukum, Universitas Jenderal Soedirman, Banyumas, 2016. Hlm. 32 
baginya. Apabila tersangka berasal dari golongan tidak mampu, hal ini diatur dalam Pasal 56 Ayat (1) KUHAP yang menyatakan bahwa dalam hal tersangka atau terdakwa disangka dan didakwa melakukan tindak pidana yang diancam dengan pidana mati atau ancaman pidana lima belas tahun atau lebih atau bagi mereka yang tidak mampu diancam dengan pidana lima tahun atau lebih. yang tidak mempunyai penasehat hukum sendiri, pejabat yang bersangkutan pada semua tingkat pemeriksaan dalam proses peradilan wajib menunjuk penasehat hukum bagi mereka. Dari keterangan pasal tersebut, tersangka/terdakwa yang tidak mampu untuk mempunyai atau mendatangkan bantuan penasehat hukum yang mana ia diancam pidana lima tahun atau lebih, maka pejabat yang bersangkutan wajib menunjuk penasehat hukum baginya. ${ }^{24}$

Ada dua sistem yang dianut dalam dunia ilmu pengetahuan hukum yang pertama dinamakam sistem "accusatoir", yang lain sistem "inquisitoir". Sistem "accusatoir" (arti kata: menuduh) menganggap seorang tersangka, yaitu pihak yang didakwa, sebagai suatu subjek berhadap-hadapan dengan pihak yang mendakwa yaitu kepolisian atau kejaksaan, sedimikian rupa, sehingga kedua belah pihak itu masing-masing mempunyai hak-hak yang sama nilainya dan hakim berada diatas kedua belah pihak itu untuk menyelesaikan soal perkara (pidana) antara mereka menurut peraturan hukum pidana yang berlaku. Sistem "inquisitoir" (arti kata: pemeriksaan) menganggap si tersangka sebagai suatu barang, suatu objek, yang harus diperiksa wujudnya berhubung dengan suatu pendakwaan. Pemeriksaan wujud ini berupa pendengaran si tersangka tentang dirinya pribadi. Oleh karena sudah ada suatu pendakwaan yang sedikit banyak telah diyakini kebenarannya oleh yang mendakwa melalui sumber-sumber pengetahuan di luar tersangka, maka pendengaran tersangka sudah semestinya merupakan pendorongan kepada tersangka, agar mengakui saja kesalahannya. Sekiranya sudah terang, bahwa di Negara Indonesia, juga berhubung dengan adanya suatu sila dari Pancasila yang merupakan perikemanusiaan, dalam hakikatnya harus dianut sistem accusatoir. Maka, dalam melakukan kewajibannya pejabat-pejabat pengusut dan penuntut perkara pidana harus selalu ingat kepada hakikat ini dan menganggap tersangka selalu sebagai seorang subjek yang mempunyai hak penuh untuk membela diri. ${ }^{25}$

Dalam menjalankan tugasnya, individu-individu atau oknum-oknum dari aparat penegak hukum tidak tertutup kemungkinan melakukan perbuatan-perbuatan yang bertentangan dengan ketentuan perundang-undangan yang berlaku dengan membuat kesalahan-kesalahan yang disengaja dan tujuan-tujuan tertentu. Perbuatan-perbuatan yang bertentangan sebagaimana dimaksud adalah suatu perbuatan yang dilakukan oleh oknum dari aparat penegak hukum terhadap tersangka atau terdakwa dengan jalan melakukan tindakan sewenang-wenang yang melanggar hak asasi seseorang atau tindakan rekayasa terhadap proses. Demikian pula halnya tindakan oknum dari aparat penegak hukum yang tidak memberikan hak-hak tersangka sewaktu dalam proses pemeriksaan pada tingkat penyidikan, hak-hak mana merupakan suatu kewajiban dari aparat penegak hukum yang harus diberikan kepada tersangka sebagaimana undang-undang mengaturnya.

Ditinjau dari segi tehnis penyidikan, proses penyidikan yang telah dijelaskan sebelumnya dinamakan prinsip accusatoir, yaitu prinsip yang menempatkan kedudukan tersangka/terdakwa dalam setiap tingkat pemeriksaan. Adalah subyek, bukan sebagi obyek pemerikaan, karena itu tersangka/terdakwa harus didudukan dan diperlakukan dalam kedudukan manusia, yang mempunyai harkat dan martabat harga diri, yang menjadi obyek pemeriksaan dalam prinsip accusatoir, adalah kesalahan tindak pidana, yang dilakukan tersangka/terdakwa, kearah itulah pemeriksaan ditujukan. Suatu kenyaaan, bahwa apriori yang menganggap tersangka/terdakwa bersalah, seolah-olah tersangka/terdakwa sudah divonis, sejak saat pertama diperiksa di hadapan pejabat penyidik. Pemeriksaan itu biasanya tidak memperdulikan hak-hak asasi manusia, dan haknya untuk mempertahankan, membela martabat serta kebenaran yang dimilikinya. Akibatnya

${ }^{24}$ Ibid., Hlm 34

25 Wirjono Prodjodikoro, 1983, Hukum Acara Pidana di Indonesia, Bandung : Sumur. Hlm. 15. 
dalam praktik penegakan hukum seseorang yang benar-benar tidak bersalah, terpaksa menerima nasib sial, meringkuk dalam menjalani hukuman beberapa tahun penjara. ${ }^{26}$

Namun, ternyata dalam pelaksanaanya, hak untuk mendapat bantuan hukum cenderung tidak diperhatikan oleh pihak kepolisian, khususnya penyidik pada saat penyidikan. Hal ini sengaja dibiarkan agar penyidik dalam penyidikannya dapat dengan leluasa mendapatkan keterangan dari tersangka berupa suatu "bentuk pengakuan", sehingga segala cara dilakukan guna mendapatkan informasi dari si tersangka, dan tidaklah mengherankan apabila kita mendengar dan membaca terjadinya penyiksaan, penganiayaan terhadap tersangka selama proses penyidikan,ini disebabkan karena budaya memperhatikan hak tersangka untuk didampingi pengacara cenderung tidak diperhatikan. Sebab, penyidik merasa terganggu pekerjaannya bila tersangka didampingi oleh advokat dan/atau pengacara. Bantuan hukum dalam rangka melindungi hak-hak tersangka pada proses penyidikan oleh kepolisian adalah hal yang sangat penting terutama dalam upaya reformasi hukum acara pidana di Indonesia. Hal tersebut dikarenakan sampai saat ini masih banyak pelanggaran HAM yang dilakukan oleh penyidik pada saat melakukan pemeriksaan terhadap tersangka. Penerapan asas accusatoir pada kenyataannya dalam proses peradilan pidana berdasarkan hasil penelitian belum maksimal menjamin perlindungan hak asasi manusia dalam sistem peradilan pidana di Indonesia. Hal ini didasarkan pada fakta bahwa ditingkat penyidikan dan penuntutan asas accusatoir penerapannya hanya terbatas pada kasus-kasus pidana yang melibatkan para pejabat dan para pemilik modal (konglomerat), sedangkan pada masyarakat umum masih diperlakukan asas inquisitoir untuk mendapatkan bukti-bukti pada tahap

\section{PENUTUP}

Bantuan hukum terhadap pelaku tindak pidana (tersangka/terdakwa) sangatlah penting dalam proses pemeriksaan perkara dalam upaya reformasi hukum acara pidana. Bantuan hukum diharapkan dapat menekan angka kekerasan pada proses pemeriksaan tersangka oleh kepolisian (penyidikan) dalam rangka melindungi Hak Asasi Manusia terhadap, maka peran bantuan hukum sangat dibutuhkan, banyaknya pemeriksaan tersangka yang tidak didampingi penasihat hukum menyebabkan terjadinya penyiksaan terhadap diri tersangka, hal tersebut kerap dilakukan karena penyidik menganggap tersangka adalah obyek pemeriksaan (prinsip Inquisitosir) bukan menempatkan tersangka sebagai subyek (prinsip accusatoir). Dengan adanya bantuan hukum diharapkan tidak terjadi kesewenang-wenangan yang dilakukan oleh penyidik terhadap terdakwa, terlebih dengan pendekatan Due Process Model yang diterapkan diharapkan akan menekan tingkat kekerasan yang dilakukan oleh penyidik terhadap tersangka pada saat proses penyidikan. Berdasarkan uraian diatas maka penulis menyarankan bahwa pengawasan pada saat proses penyidikan harus dapat dimaksimalkan sebaik mungkin hal ini menyangkut perlindungan negara terhadap warga negaranya. Selain itu pemberian bantuan hukum harus dilaksanakan sesuai dengan hukum positif yang berlaku, maksudnya tidak hanya formalitas belaka. Disamping membela hakhak tersangka bantuan hukum juga harus mampu menyadarkan para penegak hukum lainya (penyidik) agar bertindak hati-hati dalam memperlakukan tersangka pada saat penyidikan dilakukan sehingga prinsip accusatoir dapat diterapkan dengan sempurna yang akan berdampak pada reformasi hukum acara pidana yang baik.

\section{REFERENCES}

Abdul Latif, Jaminan UUD 1945 dalam Proses Hukum yang Adil, Jurnal Konstitusi, Mahkamah Konstitusi Vol. 7 No. 1. Februari, 2010.

${ }^{26}$ Syaiful Bakhari, Op.Cit., Hlm 68 
Ade Irawan Taufik, Sinergisitas Peran Dan Tanggung Jawab Advokat Dan Negara Dalam Pemberian Bantuan Hukum Cuma-Cuma, Jurnal Rechtvinding, Volume 2 Nomor 1, April 2013. Jakarta: Pusat Penelitian dan Pengembangan Sistem Hukum Nasional Badan Pembinaan Hukum Nasional (BPHN) Kementerian Hukum dan HAM RI.

Agus Raharjo, Angkasa, Perlindungan Hukum Terbadap Tersangka Dalam Penyidikan Dari Kekerasan Penyidik Di Kepolisian Resort Banyumas. Mimbar Hukum, Volume 23 Nomor 1, Februari 2011

Anggi Rahmatika, Pemberian Bantuan Hukum Terbadap Pelaku Tindak Pidana Terorisme Menurut Undangundang Nomor 16 Tabun 2011 Tentang Bantuan Hukum, Skripsi, Fakultas Hukum, Universitas Jenderal Soedirman, Banyumas, 2016.

Aswanto, 1999, Jaminan Perlindungan Hak Asasi Manusia dalam KUHAP dan Peranan Bantuan Hukum terhadap Penegakan Hak Asasi Manusia di Indonesia, Disertasi, Surabaya : Unair.

Barda Namawi Arif, 1992, Teori-Teori dan Kebijakan Pidana, Bandung : Alumni bandung.

Chrisbiantoro, M Nur Sholikin, Satrio Wirataru, 2014, Bantuan Hukum Masih Sulit Diakses : Hasil Penelitian Di Lima Provinsi Terkait Pelaksanaan Undang-Undang No. 16 Tabun 2011 Tentang Bantuan Hukum, Jakarta: KontraS.

Dian Balenina, Chintami, Partisipasi Masyarakat dalam Pengelolaan Desa Sampah Mandiri di Desa Kalisoro, Tawangmangu, Kabupaten Karanganyar, Jurnal Bestuur Vol.VII, Issue.1, Agustus, 2019

Diah Ratna Sari Hariyanto, Bantuan Hukum Bagi Orang Atau Kelompok Orang Miskin Dalam Perkara Pidana Demi Terselenggaranya Proses Hukum Yang Adil Di Denpasar, Tesis, Fakultas Hukum, Universitas Udayana, Bali, 2014.

Frans Hendra Winata I, 2011, Bantuan Hukum Di Indonesia "Hak Untuk Didampingi Penasihat Hukum Bagi Semua Warga Negara, Jakarta : PT Elex Media Komputindo.

--------, 2009, Pro Bono Publico Hak Konstitusional Fakir Miskin Untuk Memperoleh Bantuan Hukum, Jakarta : PT Gramedia Pustaka Utama.

Heidy Visilia Sahanggamu, Hak Tersangka Untuk Mendapatkan Bantuan Hukum Dalam Proses Penyidikan Perkara Pidana, Lex Crimen, Vol. II No. 2 Apr-Jun 2013.

Jamil, M. Pemalsuan Akta Autentik Sebagai Aspek Pidana Notaris, Jurnal Bestuur Vol.VII, Issue.2, December, 2019.

Jumari, Arif Potensi Pelanggaran Pengelolaan Limbah Bahan Berbahaya dan Beracun, Jurnal Bestuur Vol.VII, Issue.2, December, 2019.

Mardjono Reksodiptro, 1994, Kriminologi dan Sistem Peradilan Pidana, Kumpulan karangan buku kedua, Jakarta; Lembaga Kriminologi Universitas Indonesia.

Muladi, 1995, Kapita Selekta Sistem Peradilan Pidana, BP Universitas Diponegoro, Semarang.

Pratiwi, Ayu Dian \& Pius Triwahyudi, Jaminan Perlindungan yang Berkeadilan bagi Tenaga Kerja

Difabel Akibat Kecelakaan Kerja, Jurnal Bestuur Vol.VII, Issue.2, December, 2019.

Romli Atmasasmita, 1995, Kapita Selekta Hukum Pidana dan Kriminologi, Bandung: Mandar Maju. -------, 1996, Sistim Peradilan Pidana PerspektifEksistensialisme dan Abolisionisme, Bandung: Bina Cipta.

Sudarto, 2006, Kapita Selekta Hukum Pidana, Bandung: PT Alumni.

Syaiful Bakhari, 2014, Sistem Peradilan Pidana Indonesia Prespektif Pembaharuan Teori dan Praktik Peradilan, Yogyakarta: Pustaka Pelajar.

Wirjono Prodjodikoro, 1983, Hukum Acara Pidana di Indonesia, Bandung: Sumur.

Yolanda Putri Dewanti, Implementasi Bantuan Hukum Oleh Komisi Nasional Perlindungan Anak Kepada Anak Sebagai Korban Tindak Pidana, Skripsi, Fakultas Hukum, Universitas Jenderal Soedirman, Banyumas, 2013.

Yusriando, Konstruksi Sistem Jaminan Sosial Nasional Bidang Kesehatan, Jurnal Bestuur Vol.VII, Issue.2, December, 2019 